\title{
TRADISIONALISME DAN MODERNISME PEMBELAJARAN BAHASA ARAB: PEMBELAJARAN MADRASAH BERBASIS PESANTREN MINORITAS MUSLIM
}

\author{
Ismail Suardi Wekke*, Kisno Umbar**, Azhar Arsyad*** \\ *Sekolah Tinggi Agama Islam Negeri (STAIN) Sorong \\ **Universitas Islam Negeri (UIN) Maulana Malik Ibrahim Malang \\ ***Universitas Islam Negeri (UIN) Alauddin Makassar \\ Email: iswekke@gmail.com
}

\begin{abstract}
ABSTRAK
Pembelajaran bahasa Arab selalu dilingkupi oleh lingkungan dimana wujud proses yang berlangsung. Untuk itu, sebuah keperluan untuk meneliti bagaimana kondisi pembelajaran di madrasah minoritas muslim. Dengan demikian, penelitian ini secara khusus mengidentifikasi praktik tradisional dan modern di madrasah Papua Barat. Penelitian dilaksanakan di madrasah Sorong Raya yang meliputi Kota Sorong, Kabupaten Sorong, Kabupaten Sorong Selatan, dan Kabupaten Raja Ampat. Keempat wilayah tersebut menjadi cakupan wilayah penelitian yang dilaksanakan selama enam bulan, mulai Maret sampai Agustus 2016. Wawancara dan pengamatan dilaksanakan untuk mengumpulkan data. Makalah ini menunjukkan bahwa madrasah di minoritas muslim melakukan sinkronisasi antara metode tradisional dengan modern. Keduanya disinergikan tergantung kepada capaian pembelajaran yang hendak diwujudkan. Sementara itu, teknik seperti sorogan dan badongan juga dilaksanakan untuk melengkapi keterampilan berbahasa Arab santri. Akhirnya, makalah ini juga mendiskusikan tiga hal yang berkaitan dengan kemampuan pengelola pesantren untuk mengintegrasikan pembelajaran bahasa Arab dengan dinamika lingkungan.
\end{abstract}

Kata kunci: Metode, Madrasah, Tradisional, Modern, Pesantren.

\section{PENDAHULUAN}

Pendidikan bahasa Arab yang tumbuh dan berkembang di lingkungan madrasah berbasis pesantren senantiasa selalu mempertentangkan dua kutub antara tradisi di satu sisi dan modern di sisi yang lain. Padahal, memungkinkan sebuah pembelajaran mengaplikasikan langkah-langkah pembelajaran yang tidak seutuhnya klasik ataupun tidak sepenuhnya modern. Jika saja sebuah kelas dapat berlangsung tanpa memunculkan pertentangan ini, maka pencapaian keterampilan lebih tepat sasaran. Ini berkaitan dengan materi pembelajaran dan bagaimana seorang pengajar mencapai sasaran pembelajaran yang ingin dicapai ketika akhir pembelajaran usai. Dalam posisi seperti ini, dikotomi dua kutub ini tidak lagi relevan untuk dipertentangkan. Justru menggabungkan keduanya sesuai dengan keperluan pencapaian pembelajaran akan semakin mempermudah proses belajar (Wekke, 2015b). Pendidikan yang menggunakan pola pedagogi juga merupakan bantuan terhadap peserta didik (Ms \& Bailey, 2015). 
Sementara itu, penggunaan androgogi selamanya tidak tepat jikalau tidak melihat konteks pada pembelajaran. Untuk itu, keduanya dapat digunakan secara bersama. Hanya perlu memperhatikan kembali partisipasi setiap warga kelas (Bernales, 2016). Setiap siswa memiliki kecenderungan yang berbeda sehingga perlu membentuk lingkungan yang disesuaikan dengan keadaan siswa secara umum (Besançon \& Lubart, 2008). Untuk itu, faktor yang pelbagai tersebut merupakan bagian yang perlu diperhatikan ketika proses belajar sementara berlangsung. Persiapan yang dilakukan tenaga pengajar juga sudah perlu sejak awal melakukaan assesmen sehingga materi yang disampaikan dapat berlangsung sesuai dengan perencanaan.

Madrasah yang berada di Pesantren merupakan sebuah adaptasi yang lahir dari alam Indonesia dengan perjumpaan dari wilayah kebudayaan Islam lainnya. Bahkan berkontribusi bagi lingkungan dalam aspek sosio-ekonomi (Permani, 2011). Ketika Persia, Turki dan juga Timur Tengah menjadi bagian transfer keilmuan, maka madrasah Indonesia justru menghadirkan corak yang sama sekali berbeda dengan semua itu. Kehadirannya senantiasa tumbuh dari masyarakat dan menjadikan masyarakat sebagai bagian dari pola pengembangan. Madrasah dengan segala variasinya melampau harapan, cita-cita, dan semangat para pendirinya. Hari ini, madrasah telah menjadi bagian dari arus utama perjalanan kebangsaan. Bahkan turut mendukun terwujudnya Indonesia. Tidak dalam pendidikan semata tetapi juga dalam aspek kehidupan yang luas. Bahkan, setiap perhelatan kebangsaan, madrasah sudah hadir dalam posisi itu sekaligus memainkan peran yang nyata untuk kemasalahan umat manusia. Hanya saja, kalau problematika pembelajaran bahasa Arab dapat ditemukan solusinya, maka loncatan daya saing untuk kemajuan yang dapat dicapai akan terbentang lebih jauh lagi. Dalam posisi seperti ini, jika di fase awal madrasah menemukan tantangan untuk bertahan, kini madrasah justru sudah berada dalam tahap dimana pemberdayaan masyarakat, gerakan masyarakat madani, dan bagian dari kekuatan sosial, adalah ritme perjuangan keseharian. Pendidikan tetaplah sebagai sumbu utama aktivitasnya. Bahkan di wilayah minoritas muslim seperti Finlandia, pendidian menjadi bagian untuk pengembangan masyarakat (Rissanen, 2012).

Madrasah dengan perangkat pembelajarannya masih saja ada yang berlangsung dalam kondisi tertentu sebatas formalitas. Ini dapat kita temukan ketika mahasiswa berada 
di bangku perguruan tinggi. Penguasaan dasar terhadap khazanah keilmuan masih saja belum sempurna. Padahal, ketika menginjakkan kaki di bangku pendidikan tinggi, maka pondasi keilmuan sudah mesti tertanam dalam pendidikan dasar dan menengah, bagi memudahkan pendidikan di tingkatan tertinggi. Hanya saja, harapan ini kadang pupus karena pendidikan dasar dan menengah tidak merumuskan interaksi pendidikan secara maksimal. Dengan demikian, diperlukan sebuah langkah untuk mendorong proses pembelajaran di madrasah kita dapat menjadi pondasi bagi masa depan. Hanya saja, keterbatasan waktu sekaligus tidak tepatnya metode pembelajaran menjadikan kelas hanya menjadi sebuah ritual semata. Setelahnya, setiap tingkatan pendidikan bukanlah menjadi kelanjutan dari apa yang ada dalam proses sebelumnya. Justru mereka kemudian harus mengurai masalah yang muncul dan tidak terselesaikan pada bagian sebelumnya. Kemampuan yang diperoleh di jenjang sebelumnya, menjadi daya dukung bagi proses pendidikan di bangku perguruan tinggi (Hamka, 2009).

Kebosanan dan kejenuhan senantiasa melingkupi kelas. Pada akhirnya, menjalani pendidikan hanyalah keterpaksaan semata. Pola belajar yang mengikuti siklusnya sampai kepada ujian semata-mata orientasi tahunan. Kalau ini dipertahankan, maka pendidikan Indonesia menjadi alat bagi kepentingan bukan untuk pengetahuan dan kesejahteraan peradaban. Bukan juga karena target yang justru ditentukan oleh institusi di luar pendidikan itu sendiri. Tantangan ini menjadi sebuah kesempatan untuk tidak menemukan kata berhenti bagi menemukan solusi demi solusi untuk mendapatkan pembelajaran cemerlang. Salah satu pilar utama untuk menggerakkan kemandegan ini adalah hadirnya guru yang menjalankan tugasnya dengan sepenuh pengabdian.

Tradisi Kulliyah Muallimin Indonesia (KMI) yang juga secara popular disebut Gontor menunjukkan bahwa tidak ada yang lebih berharga dibandingkan dengan guru. Merekalah yang memandu setiap langkah murid-muridnya dalam proses pembelajaran. Keterampilan mengelola kelas walaupun bukan segala-galanya tetapi ini akan menjadi faktor utama dalam penyelenggaraan pembelajaran. Sarana dan prasarana yang terbatas, media pendidikan yang tidak memadai, buku ajar yang tidak lengkap, dan kekurangan tenaga kependidikan, tidaklah menjadi penghalang bagi capaian pendidikan. Ini semua dapat terjadi karena masih hadirnya sosok guru yang menginspirasi murid-muridnya untuk 
terus belajar. Dari Gontorlah kita dapat belajar bahwa kepribadian guru akan menjadi katalisator bagi metode dan hasil yang memadai. Masing-masing santri berkembang sebagaimana keterampilan yang diasah dan minat yang digeluti. Keberhasilannya dapat dicapai karena berhasil memupuk minat dan spirit bagi pembelajaran yang berkelanjutan. Status guru yang dilambangkan dengan penutur asli ataupun guru dengan kemampuan bahasa kedua tidaklah menjadi faktor penting (Hobbs, Matsuo, \& Payne, 2010). Justru diperlukan kemampuan untuk memandu pembelajaran di dalam dan luar kelas.

Modernitas pendidikan tidak semata-mata karena menggunakan perkembangan teknologi komunikasi dan informasi. Justru nilai kemoderean dalam pendidikan akan menemukan makna jikalau saja kesediaan untuk menggunakan apa yang menjadi keunggulan dari bidang dan otoritas yang lain. Pada setiap penemuan baru, maka masa lalu tidak dapat dilepaskan dari apa yang ada saat ini. Kaitan dengan apa yang menjadi bagian masa lampau justru akan berkaitan dengan masa kini sebagai kesinambungan. Posisi seperti dapat terjadi jikalau kelas senantiasa diorganisasikan dalam kerangka mencapai tujuan yang tidak hanya sesaat. Guru dengan memberikan penguatan, pemahaman yang komprehensif, ilustrasi dari sebuah ide yang abstrak, dan struktur informasi yang relevan, kesemuanya menjadi bagian dari pemusatan perhatian peserta didik untuk mengembangkan ilmu pengetahuan yang tidak hanya disebut dengan mata pelajaran. Masyarakat yang dihuni dengan anggotanya yang menjadi orientasi pada ilmu pengetahuan akan senantiasa menemukan jawaban bagi interaksi yang didasari atas norma kebaikan dan keluhuran budi pekerti.

Dalam konteks Madrasah, keinginan belajar yang didasari dengan spirit keberagamaan merupakan potensi yang tidak terbatas untuk menemukan dalam mewujudkan pendidikan yang tidak bermakna pengajaran saja. Dalam posisi ini pula, konteks modern dapat bersua dengan tradisional. Ketika pola yang diwarisi dari masa lalu tetap dapat bertahan, maka tidak tertutup kemungkinan untuk menghadirkan atau mengembangkan sebuah inovasi baru. Justru dengan berdasar pada akar yang sudah mapan kemudian ditambahkan dengan pengembangan mutakhir, maka ini menjadi sebuah kesempatan hadirnya pembaruan. Hasilnya akan dipetik dengan adanya sebuah transformasi kelembagaan sekaligus bertambahnya khazanah peradaban Islam dari segi 
pendidikan. Secara khusus makalah ini menganalisis keperluan untuk menggabungkan antara prinsip-prinsip pembelajaran tradisional dan modern dalam proses pembelajaran di madrasah, khususnya madrasah yang berbasis pesantren.

\section{MODEL DAN METODE PEMBELAJARAN BAHASA ARAB}

Pembelajaran bahasa Arab tradisional dengan mempergunakan metode utama tarjamah (terjemah) dan qawaid (tata bahasa) merupakan pilihan yang mudah dan memudahkan. Setiap guru, tidak perlu melakukan persiapan secara khusus. Cukup berbekal kitab yang akan diajarkan kemudian pembelajaran dapat terjadi begitu saja. Dengan kelas yang berukuran besar, memungkinkan model ini dapat dilaksanakan dimana saja. Kemampuan yang diajarkan juga merupakan keterampilan yang sangat dibutuhkan untuk fase awal dalam belajar bahasa Arab. Tidak saja untuk membaca dan menulis, pada saat yang sama diperlukan kemampuan untuk bertutur dan menulis. Keempat keterampilan berbahasa akan menjadi daya dukung kepakaran dan kapasitas seorang cendekiawan.

Selanjutnya, model pembelajaran bahasa Arab modern. Untuk model pembelajaran bahasa Arab di tingkat tsanawiyah atau Aliyah dengan berbasis pondok pesantren, Gontor menjadi pilihan dalam mewujudkan pembelajaran bahasa Arab yang memungkinkan penguasaan keterampilan berbahasa yang sangat memadai. Pembelajaran bahasa Arab dengan model Gontor ini kemudian diadaptasi pelbagai lembaga ke seluruh pelosok tanah air. Lembaga pendidikan yang diprakarsai alumni Gontor sudah jamak menggunakan model ini. Beberapa lembaga yang didirikan alumni Gontor mengadakan beberapa pembaruan sehingga menghasilkan lulusan yang sesuai dengan keperluan lembaga, seperti Darunnajah di Jakarta. Bahkan walaupun tidak diprakarsai oleh alumni Gontor tetap saja beberapa lembaga menggunakan model ini. Pesantren IMMIM di Makassar, termasuk lembaga pendidikan yang diinspirasi oleh keberhasilan pendidikan Islam dengan pola Gontor. Sehingga pihak Dewan Pengurus Pusat Ikatan Masjid Mushallah Indonesia Muttahidah (IMMIM) memutuskan untuk mengelola lembaga pendidikan dengan Gontor sbagai acuan awal (Wekke, 2012). Program dengan model Gontor menjadi sebuah pilihan untuk dikembangkan di sekolah menengah. 
Begitu juga dengan pendidikan bahasa Arab dengan penguatan pada studi Islam. Model pembelajaran ma'had yang diselenggarakan Pimpinan Pusat Muhammadiyah dengan Asian Muslim Charity Foundation (AMCF) di 14 pendidikan tinggi Muhammadiyah merupakan sebuah alternatif yang memadai. Keberadaan lembaga pendidikan dengan fokus pada studi Islam mulai diadaptasi juga di lembaga pendidikan lain dengan juga sebutan "ma'had". Pembelajaran bahasa Arab di perguruan tinggi dilaksanakan secara intensif dilaksanakan di perguruan tinggi keagamaan Islam seperti Universitas Islam Negeri Maulana Malik Ibrahim, Malang. Program belajar bahasa Arab dilaksanakan selama setahun dengan program yang dirancang untuk memberikan bekal bahasa Arab sebagai kemampuan untuk menekuni studi Islam. Begitu juga di Universitas Islam Negeri Alauddin, Makassar. Dilaksanakan Program Intensifikasi Bahasa Asing (PIBA) untuk dua semester dengan memberikan penguatan pada bahasa Arab dan bahasa Inggris ditambah dengan materi retorika.

\section{KEKHASAN MADRASAH IBTIDAIYAH}

Sekolah Dasar Islam Terpadu (SDIT) dijadikan sebagai alternatif lembaga pendidikan Islam. Tidak saja pada tingkatan pendidikan dasar, kemudian dikenal pula Sekolah Menengah Pertama Islam Terpadu (SMPIT) dan Sekolah Menengah Atas Islam Terpadu (SMAIT). Pengelolaan SDIT menjadi sebuah tahapan awal dalam mendapatkan model pembelajaran bahasa Arab di tingkat pendidikan dasar. Walaupun bukan bahasa Arab yang menjadi program utama tetapi terdapat kekhasan dengan pengembangan materi Quran yang terintegrasi dengan materi belajar bahasa Arab. Tidak saja memudahkan untuk belajar Quran tetapi pada kesempatan yang sama akan menjadi latihan dalam memperkuat keterampilan berbahasa Arab.

Madrasah Ibtidaiyah Negeri Malang I menjadi sebuah contoh. Madrasah tersebut memilik waktu yang terbatas, dengan kurikulum nasional yang sama dengan madrasah lainnya. Hanya saja, dilakukan pengayaan keterampilan berbahasa dalam program-program mata pelajaran lain. Ditambahkan pula dengan materi belajar diluar jam pelajaran untuk memperkaya kemampuan berbahasa Arab. Hasilnya, tidak saja pengetahuan secara kognitif 
saja tetapi keterampilan berbahasa Arab dalam bentuk muhadatsah dan insya dikuasai ketika menamatkan pendidikan madrasah ibtidaiyah.

Sekolah Dasar Islam Terpadu Al-Izzah merupakan salah satu sekolah yang menggunakan integrasi mata pelajaran bahasa Arab dengan mata pelajaran lain terutama pada materi yang berhubungan dengan Quran. Secara utuh, materi Quran berhubungan dengan bahasa Arab sehingga di beberapa perguruan tinggi Jerman dikembangkan bahasa Arab secara khusus untuk menguasai Alquran. Dengan pandangan yang berbeda tetapi dengan melaksanakan kegiatan yang hamper sama, SDIT Al-Izzah menggunakan waktu pembelajaran Quran untuk memberikan penguatan pada kemampuan berbahasa. Dengan pembelajaran yang terstruktur tidak saja penguasaan Quran yang diperoleh tetapi pada saat yang sama diperoleh pula kemampuan berbahasa Arab. Kemampuan bahasa Arab inilah yang menunjang kemampuan membaca Quran dan juga program integrasi lainnya.

Pada madrasah ibtidaiyah, keterampilan berbahasa Arab dapat dibagi pada dua kelompok besar yaitu kelas rendah dan kelas tinggi. Pada tiga tahun pertama, kemampuan berbahasa Arab dapat diintegrasikan dengan keterampilan membaca Alquran. Contohcontoh yang dikemukakan dapat menggunakan kata atau kalimat dari Alquran. Sementara pada tingkatan kelas atas, mulai diperkenalkan pola kalimat yang dapat membantu untuk menggunakan kata dan kalimat itu dalam kegiatan percakapan sehari-hari. Dua kelas terakhir, dapat dikembangkan dengan proses belajar menulis. Sehingga dalam dua tahun, murid memiliki kemampuan menulis huruf-huruf hijaiyah sudah sesuai dengan standar penulisan khat. Enam tahun sebagai waktu yang memungkinkan untuk menyiapkan murid sehingga mampu untuk menekuni proses belajar di sekolah menengah.

\section{IMPLIKASI TEORITIS}

Penelitian Tindakan Kelas (PTK) kadang khusus memperhatikan peningkatan keterampilan saja. Padahal proses pembelajaran sejatinya perlu melihat keadaan secara luas. Tidak saja berkaitan dengan peningkatan keterampilan. Ada pertanyaan lain sehubungan dengan pemilihan penelitian tindakan kelas, akan ada pertanyaan lain yang perlu dijawab "apa kontribusi keilmuan” yang menjadi dampak bagi pelaksanaan PTK. Dalam beberapa aktivitas PTK, hanya persoalan peningkatan keterampilan yang dijadikan 
sebagai perhatian utama. Sebagai aktivitas penelitian, maka sumbangan terhadap keilmuan merupakan tuntutan utama. Sehingga diperlukan adanya sebuah sumbangsih yang lebih besar dibanding hanya membuktikan bagaimana sebuah model atau metode digunakan dalam ruang kelas.

Dalam PTK mata pelajaran bahasa Arab, maka diperlukan sebuah inovasi tidak saja dalam bentuk pembelajaran kelas tetapi juga perlu memperhatikan kesatuan dengan mata pelajaran lainnya. Begitu pula dengan mata pelajaran bahasa Arab di kelas yang lain. Dengan integrasi seperti ini memungkinkan untuk menjalin proses yang komprehensif untuk menyelesaikan capaian belajar. Keterkaitan dengan mata pelajaran lain dalam kesatuan kurikulum lebih mudah jikalau dipantau oleh guru di madrasah ibtidaiyah. Hanya beberapa madrasah yang menugaskan kepada guru tertentu untuk mengampu mata pelajaran bahasa Arab sebagai guru tersendiri. Sementara dalam madrasah dengan keterbatasan guru, mata pelajaran bahasa Arab diampuh oleh guru kelas. Keduanya masingmasing memiliki keterbatasan dan keunggulan. Jikalau fokus kepada keunggulan masingmasing, maka dapat saja dicapai proses belajar yang tetap memenuhi kriteria dan bahkan bisa mencapai hasil yang maksimal. Bahkan bisa saja dilakukan sebuah pembelajaran yang tidak hanya mengandalkan tatap muka tetapi perlu mempergunakan media pembelajaran yang berbasis teknologi informasi. Walaupun dilaksanakan dengan jarak jauh, perkembangan peserta didik tetap saja dapat berlangsung (Gijselaers, Kirschner, Verboon, \& Groot, 2016). Hanya saja, dengan tatap muka aspek emosi dan inetraksi menjadi keunggulan dibandingkan dengan hanya menggunakan alat-alat tertentu (Marchand \& Gutierrez, 2012).

Belajar bahasa Arab sebagai bagian dari aktivitas keberagamaan. Tanpa mengenyampingkan bahasa lain, bahasa Arab diperlukan untuk pembentukan kemampuan ibadah seorang muslim. Jikalau ini dikuasai, maka komunikasi dengan Sang Pencipta dapat terbentuk dengan lebih mudah. Meletakkan kemampuan berbahasa Arab berada di fase madrasah ibtidaiyah. Sehingga ini menjadi modal selanjutnya untuk pengembangan keilmuan seorang murid. Ketika menguasai bahasa Arab di madrasah ibtidaiyah, maka pada proses belajar di tsanawiyah ataupun Aliyah, kecintaan terhadap bahasa Arab sudah dipupuk sejak awal. Mereka kemudian tidak saja berusaha mengikuti materi belajar yang 
berhubungan dengan bahasa Arab tetapi juga berkaitan dengan pemilihan jurusan di perguruan tinggi. Dari pembelajaran bahasa Arab di madrasah ibtidaiya-lah yang akan menjadi awal dari segala proses belajar di masa yang akan datang. Ketika individu musli menguasai bahasa Arab, maka ini berkaitan dengan kemampuan dalam memahami ajaran Islam secara komprehensif. Secara makro, penguasaan bahasa Arabpun akan berdampak bagi pemahaman hukum Islam (Yusuf dan Wekke, 2012).

Memperhatikan model pembelajaran yang terbagi atas dua model jikalau mempergunakan kategori pada penguasaan keterampilan yaitu tradisional dan modern. Sementara model berkaitan dengan tingkatan pendidikan terdiri atas tiga yaitu pendidikan dasar, pendidikan menengah, dan pendidikan tinggi. Model-model kesemuanya memiliki ciri khas yang tersendiri yaitu program intensif. Untuk penguasaan bahasa Arab tidak akan pernah didapatkan jikalau tidak dilakukan secara terstruktur, terprogram, dan dalam waktu yang berkesinambungan. Jikalau hanya menggunakan struktur kurikulum formal dan waktu yang terbatas, maka harapan yang diiginkan tidak akan pernah terwujud. Relasi mengajarbelajar dibangun secra produktif sehingga baik guru maupun siswa dapat mengembangkan kemampuan masing-masing (Liu \& Xu, 2011). Demikian pula sejak awal perlu dibangun alur yang tepat dengan memulai dari aspek ontologi keilmuan sampai pada bagian aksiologi (Horsfall, Cleary, \& Hunt, 2012). Kemampuan ini akan membantu guru dalam mengawal seluruh proses belajar.

Kajian pembelajaran bahasa di minoritas muslim merupakan sebuah keperluan yang mendukung pelaksanaan pendidikan. Beberapa kajian yang sudah dipublikasikan masih sebatas fokus pada identitas (Al-romi, 2000), makanan halal (Bonne \& Verbeke, 2008)(Henderson, 2016), akulturasi dan adaptasi (Kunst \& Sam, 2013), dan diskriminasi (Wright, Wallace, Bailey, \& Hyde, 2013). Padahal, sebuah model pembelajaran bahasa Arab di minoritas muslim (Wekke, 2015) menjadi alternatif pengembangan pendidikan. Kurikulum yang dikembangkan disesuaikan dengan kondisi dan kekhasan lingkungan (Wekke, 2014). Salah satu alternatif adalah dengan mengembangkan pembelajaran aktif (Yusuf \& Suardi, 2015). Sebagaimana pula di Asia Selatan, madrasah menjadi daya dorong bagi masyarakat (Park \& Niyozov, 2008). 
Pembelajaran bahasa Arab tidak akan pernah terwujud secara ideal jikalau tidak bekerja secara tim. Pengalaman di beberapa lembaga pendidikan Islam, justru dengan partisipasi masyarakat akan memberikan penguatan pengelolaan dan juga tercapaianya program-program yang lebih besar (Rahman, 2014). Untuk mengembangkan model pembelajaran bahasa diperlugakn sinergitas antar kelompok dan lembaga di masyarakat Islam. Secara mandiri sebuah lembaga tidak dapat berjalan sesuai harapan tanpa adanya dukungan dari pihak lain. Sehingga kolaborasi akan menjadi kesempatan dalam mewujudkan harapan bersama.

\section{PENUTUP}

Dengan mengembangkan model termasuk turunannya dalam metode, maka pembelajaran bahasa Arab dapat diselesaikan bahkan melampaui target kurikulum. Memperhatikan keperluan di madrasah ibtidaiyah, maka diperlukan sebuah inovasi sehingga pembelajaran di madrasah ibtidaiyah dapat dilaksanakan dengan tidak saja dengan sasaran pada kurikulum tetapi juga sudah menjadi landasan bagi proses belajar berikutnya. Kesempatan selama enam tahun untuk memberikan pengalaman belajar, merupakan kesempatan terbaik dalam pengenalan bahasa Aran dan penguasaannya. Selama enam tahun itu, secara berjenjang pembelajaran akan diberikan secara bertahap dan berjenjang sehingga ada penguasaan berbahasa yang terstuktur. Diperlukan sebuah model sekaligus metode yang bervariasi untuk memberikan kesempatan kepada setiap murid untuk belajar bahasa Arab.

Pembelajaran bahasa Arab memerlukan inovasi dan juga kesungguhan pelaksanaan. Selama ini kegagalan pembelajaran bahasa Arab karena tidak dijadikan sebagai program utama. Berbeda halnya dengan lembaga-lembaga yang menjadikan bahasa Arab sebagai program utama, maka keterampilan bahasa Arab menjadi bagian utama yang memberikan "ruh" bagi pelaksanaan program yang dijalankan. Sementara itu, materi bahasa Arab kadang hanya dijadikan sebagai pelengkap sebuah program dan bukan dijadikan sebagai program itu sendiri. Sehingga pencapaian keterampilan berbahasa Arab tidak dijadikan sebagai unsur utama evaluasi pelaksanaan kegiatan 


\section{DAFTAR PUSTAKA}

Al-romi, N. H. (2000). Muslims as a minority in the United States. International Journal of Educational Reseacrh, 33, 631-638.

Bernales, C. (2016). Towards a comprehensive concept of Willingness to Communicate : Learners ' predicted and self-reported participation in the foreign language classroom. System, 56, 1-12.

Besançon, M., \& Lubart, T. (2008). Differences in the development of creative competencies in children schooled in diverse learning environments. Learning and Individual Differences, 18(4), 381-389.

Bonne, K., \& Verbeke, W. (2008). MEAT Muslim consumer trust in halal meat status and control in Belgium. Meat Science, 79, 113-123.

Gijselaers, H. J. M., Kirschner, P. A., Verboon, P., \& Groot, R. H. M. De. (2016). Sedentary behavior and not physical activity predicts study progress in distance education. Learning and Individual Differences, 49, 224-229.

Hamka. (2009). Rekonstruksi kurikulum pendidikan agama islam di perguruan tinggi umum pascapemerintahan orde baru. Jurnal Hunafa, 6 (1), 24.

Henderson, J. C. (2016). Halal food, certi fi cation and halal tourism: Insights from Malaysia and Singapore. Tourism Management Perspectives, 19, 160-164.

Hobbs, V., Matsuo, A., \& Payne, M. (2010). Code-switching in Japanese language classrooms : An exploratory investigation of native vs . non-native speaker teacher practice. Linguistics and Education, 21(1), 44-59.

Horsfall, J., Cleary, M., \& Hunt, G. E. (2012). Nurse Education Today Developing a pedagogy for nursing teaching - learning. Nurse Education Today, 32(8), 930-933.

Kunst, J. R., \& Sam, D. L. (2013). Relationship between perceived acculturation expectations and Muslim minority youth' $\mathrm{s}$ acculturation and adaptation. International Journal of Intercultural Relations, 37(4), 477-490.

Liu, Y., \& Xu, Y. (2011). Inclusion or exclusion ?: A narrative inquiry of a language teacher" s identity experience in the " new work order" of competing pedagogies. Teaching and Teacher Education, 27(3), 589-597.

Marchand, G. C., \& Gutierrez, A. P. (2012). Internet and Higher Education The role of emotion in the learning process: Comparisons between online and face-to-face learning settings. The Internet and Higher Education, 15(3), 150-160.

Ms, D. E. C., \& Bailey, L. E. (2015). Narrative pedagogy amidst program accountability : Helping nontraditional nursing students who must repeat a course. Teaching and Learning in Nursing, 10(4), 161-168.

Park, J., \& Niyozov, S. (2008). Madrasa education in South Asia and Southeast Asia: current issues and debates. Asia Pacific Journal of Education, 28(4), 323-351.

Permani, R. (2011). The presence of religious organisations, religious attendance and earnings : Evidence from Indonesia. Journal of Socio-Economics, 40(3), 247-258.

Rahman, K. (2014). Peningkatan Mutu Madrasah melalui Penguatan Partisipasi Masyarakat, Jurnal Pendidikan Islam, Vol. 1 (2), 227-246.

Rissanen, I. (2012). Teaching Islamic education in Finnish schools: A fi eld of negotiations. Teaching and Teacher Education, 28(5), 740-749. 
Wekke, I. S. (2012). Amalan pengajaran dan pembelajaran bahasa arab di pesantren immim Makassar, Indonesia. Disertasi. Bangi: Fakulti Pendidikan, Universiti Kebangsaan Malaysia.

Wekke, I. S. (2014). Tradisi pesantren dalam konstruksi kurikulum bahasa arab di lembaga pendidikan minoritas muslim papua barat. KARSA: Jurnal Sosial dan Budaya Keislaman, 22(1), 21-39.

Wekke, I. S. (2015a). Arabic Teaching and Learning: A Model From Indonesian Muslim Minority. Procedia - Social and Behavioral Sciences, 191, 286-290.

Wekke, I. S. (2015b). Antara Tradisionalisme dan Kemodernan: Pembelajaran Bahasa Arab Madrasah Minoritas Muslim Papua Barat. Jurnal Peradaban Islam Tsaqafah, 11(2), November 2015, 313-332.

Wright, B. R. E., Wallace, M., Bailey, J., \& Hyde, A. (2013). Religious affiliation and hiring discrimination in New England: A field experiment. Research in Social Stratification and Mobility, 34, 111-126.

Yusuf, M., \& Wekke, I. S. (2015). Active Learning on Teaching Arabic for Special Purpose in Indonesian Pesantren. Procedia - Social and Behavioral Sciences, 191, 137-141.

Yusuf, M., dan Wekke, I. S. (2012). Menelusuri Historisitas Pembentukan Hukum Islam: Menggagas Yurisprudensi Islam Indonesia. Jurnal Peradaban Islam Tsaqafah, 8(2), Oktober, 369-392. 